\title{
Grey poplar explant acclimation to improve the dehydration tolerance and cryopreservation
}

\author{
E. POKORNÁ ${ }^{1 *}$, M. FALTUS ${ }^{2}$, P. MÁCHOVÁ ${ }^{1}$, J. ZÁMEČNÍK², and M. FULÍN ${ }^{1}$ \\ Forestry and Game Management Research Institute, CZ-25202 Jíloviště, Czech Republic ${ }^{l}$ \\ Crop Research Institute, CZ-16106 Prague, Czech Republic ${ }^{2}$
}

\begin{abstract}
Cryostorage techniques have been developed to preserve the most valuable genotype from an endangered native population of Populus $\times$ canescens Aiton Sm. (grey poplar), which is located in the floodplain forest in the South Moravia region of the Czech Republic and which is difficult to propagate using cuttings. The prevailing genotype with valuable traits was selected by the simple sequence repeats method. This genotype was used to determine the most effective pre-cultivation conditions (cold hardening, and cold hardening combine with osmotic treatment) on dehydration tolerance and post-thaw recovery of the grey poplar shoot tips. The pre-cultivation and application of a modified plant vitrification solution 3 (PVS3) considerable reduced the freezable water content in shoot tips. Evaluation after eight weeks of regrowth revealed that simultaneous effect of cold and osmotic pre-treatments and application of PVS3 for 120 min enabled $93.3 \pm 5.8 \%$ recovery. The results emphasize the importance of the pre-cultivation conditions, which significantly improved the postthaw recovery of the grey poplar explants.
\end{abstract}

Additional key words: apical segments, cold hardening, cryopreservation, Populus $\times$ canescens, SSR analysis, vitrification solution.

\section{Introduction}

Populus $\times$ canescens Aiton Sm. (grey poplar), a spontaneous hybrid of Populus alba L. and Populus tremula L., belongs among the woody plant species characterized by a fast growth rate with a relatively low nutrient demand and wide distribution in the river basins (Úradníček et al. 2009). Generally, Populus species have been previously utilized as a source of pulp and wood products, but recently, an interest in poplar significantly arose mainly due to the short rotation forestry regimes leading to production chips or pelletized wood fuel or feedstock for lignocellulosic bioethanol outputs (Guo et al. 2014). In the South Moravia region of the Czech Republic, a unique population of grey poplar specified by valuable traits, such as a narrow crown and a straight continuous trunk with natural pruning, has been determined in a floodplain forest (Buriánek and Novotný 2016). Based on a high interest to preserve the valuable phenotypic traits of grey poplars characterized by relatively high age and low effectivity of classical vegetative propagation by cutting or grafting, cryopreservation is promisive method with long-term perspective. For experimental work, the most abundant genotype in the population based on determination of genetic traits was selected, which is very important for future strategy in forest management.

The preservation of viable cells, tissues, and organs in liquid nitrogen $\left(\mathrm{LN},-196^{\circ} \mathrm{C}\right)$ represents a long-term storage method mainly used for plant genetic resources, which cannot be maintained via conventional preservation techniques, similar to recalcitrant seeds, vegetatively propagated specific cultivars or unique ornamental genotypes (Benson 1999, Ryynänen 1999, Kacmarczyk et al. 2012). The cryopreservation has also been applied for rare and endangered species such as tropical forest trees or clonally propagated trees (Reed 2001, Wilkinson et al. 2003, Pritchard et al. 2014). There are several approaches and protocols for the cryopreservation of individual plant tissues in LN. In general, plant material with a high amount of cell water and thus endangered by intracellular water crystallization (buds, shoot tips, nodal segments, embryos, calli, and cell suspension) has to be

Submitted 3 March 2019, last revision 23 October 2019, accepted

Abbreviations: DSC - differential scanning calorimetry; LN - liquid nitrogen; LS - loading solution, MS - Murashige and Skoog; PVS - plant vitrification solution; SSR - simple sequence repeats.

Acknowledgements: The authors thanks J. Dostál, Z. Hybnerová and A. Čajková for technical support. This study was funded by the Ministry of Agriculture of the Czech Republic (institutional supports MZE-RO0118 and MZE-RO0418, and project No. QK1910277).

* Corresponding author; e-mail: pokorna@vulhm.cz 
protected by dehydration before freezing in contrast to the direct cryopreservation of some plant material in which natural dehydration processes occur (Benelli et al. 2013). Vitrification-based techniques represent a simplified cryogenic procedure based on plant tissue dehydration achieved by treatment with cryoprotectant compounds following by immersion in highly concentrated vitrification solutions prior to storage in LN (Danso and Ford-Lloyd 2011). In addition, the vitrification enables the transition of water from the liquid phase into an amorphous phase or glassy-state structure to avoid the nucleation of the ice crystals (Fahy et al. 1984). The phase transitions of the plant materials associated with temperature change and heat flow are measured by differential scanning calorimetry (DSC), which precisely monitors the heat quantity radiated or excessively absorbed by the sample during a change of temperature within a time (Gill et al. 2010). To date, a thermal analysis approach in combination with the vitrification technique has been applied throughout the plant kingdom, also including woody plant species (Ryynänen and Aronen 2005, Vidal et al. 2005, Uchendu et al. 2010, Gantait et al. 2015).

A widely used plant vitrification solution 2 (PVS2) containing $30 \%(\mathrm{~m} / \mathrm{v})$ glycerol, $15 \%(\mathrm{~m} / \mathrm{v})$ polyethylene glycol, and $15 \%(\mathrm{v} / \mathrm{v})$ dimethylsulfoxide in a liquid Murashige and Skoog (MS, 1962) medium with $0.4 \mathrm{M}$ sucrose (Sakai et al. 1990) was also applied during the vitrification procedures of Populus spp. germplasm preservation. Jokipii et al. (2004) tested three different cryopreservation protocols and found that the slow cooling method used for $P$. tremula $\times P$. tremuloides buds in vivo resulted in the highest regeneration percentages (72 - $96 \%)$ in comparison to PVS2 treatment (22.5 $65 \%$ ), whereas slow cooling in polyethylene glycol, glucoseand dimethylsulfoxide solution containing $10 \%$ $(\mathrm{m} / \mathrm{v})$ polyethylene glycol 6000, $10 \%(\mathrm{~m} / \mathrm{v})$ glucose, and $10 \%(\mathrm{v} / \mathrm{v})$ dimethylsulfoxide used for in vitro grown apical segments resulted in a recovery percentage of $1.1 \%$. Alternatively, Lambardi et al. (2000) presented an efficient one-step vitrification procedure using PVS2 for the shoot tips of $P$. alba with almost $60 \%$ of the rooted shoots originating from LN storage. A similarly high postfreeze survival rate $(78 \%)$ of white poplar shoot tips after using the PVS2 vitrification protocol was demonstrated by Tsvetkov et al. (2009). Interestingly, several studies reported a superior effect of alternative plant vitrification solutions modified from the original PVS2 by increasing the glycerol and sucrose concentrations and/or omitting DMSO and polyethylene glycol in many plant species (Storme et al. 2004, Kim et al. 2009, Kaviani 2011, Nuc et al. 2016), but currently, no data on the PVS3 application are available for poplar species.

Among the factors that may substantially affect the effectiveness of the germplasm cryopreservation are appropriate plant genotypes, which are currently generally characterized by molecular markers (Sales et al. 2001). The selection of valuable genetic resources for cryopreservation and the determination of genetic diversity at a group or subgroup using the simple sequence repeats (SSR) method was widely applied to, e.g., dessert apple germplasm (Urrestarazu et al. 2016) or avocado species (Guzmán et al. 2017). In Populus, the patterns of genetic variation described by the SSR markers have been developed to estimate the genetic structure within and among populations, species, and hybrids, or for other purposes (Storme et al. 2004, Van Loo et al. 2008, Liesebach et al. 2010, Politov et al. 2015) but not in terms of the long-term storage of poplar germplasm.

The objective of this study was to develop a cryopreservation method appropriate for the conservation of a unique grey poplar genotype based on a vitrification procedure and previous explant acclimation. The SSR method was used to identify genotypes within the grey poplar population, and differential scanning calorimetry was used to determine the optimal tissue hydration. The hypothesis that explant preculture, increasing their tolerance to dehydration, and a significant reduction in the freezable water content can improve the cryotolerance of grey poplar shoot tips has been tested.

\section{Materials and methods}

Genotype selection using nuclear microsatellite markers: Thirty samples of grey poplar (Populus $\times$ canescens Aiton Sm.) individuals were collected from the floodplain forest at the Dyjákovice village in the South Moravia, Czech Republic. Total genomic DNA was extracted from $20 \mathrm{mg}$ of dry young leaf using a DNeasy plant mini kit (Qiagen, Valencia, CA, USA) according to the manufacturer's instructions. Quality and quantity of DNA was determined using a spectrophotometer (NanoPhotometer, Implen, München, Germany) and stored at $-20{ }^{\circ} \mathrm{C}$. Genetic variation was analysed by using the nine previously characterized polymorphic nuclear microsatellite markers ORPM16, ORPM220, ORPM30, ORPM312, WPMS15, WPMS5, ORPM60, WPMS16, and ORPM20 (Van der Schoot et al. 2000, Smulders et al. 2001, Tuskan et al. 2004, Van Loo et al. 2007; http:// www.ornl.gov/sci/ipgc/ssr_resource.htm). Fluorescently labelled primers have been sorted into the two multiplexes and used for fragment amplification. Polymerase chain reaction cycles consisted of a denaturing step at $94{ }^{\circ} \mathrm{C}$ for $3 \mathrm{~min}$, followed by 35 cycles of $94{ }^{\circ} \mathrm{C}$ for $45 \mathrm{~s}, 55^{\circ} \mathrm{C}$ for $45 \mathrm{~s}$, and $72{ }^{\circ} \mathrm{C}$ for $45 \mathrm{~s}$, with a final elongation step at $72{ }^{\circ} \mathrm{C}$ for $20 \mathrm{~min}$. The size of the amplified fragments was determined on an Applied Biosystems (Foster City, CA, USA) 3500 sequencer using the capillary electrophoresis method. The alleles were sized based on the GeneScan ${ }^{\mathrm{TM}}-600$ LIZ $^{\mathrm{B}}$ size standard v. 2.0 (Applied Biosystems), subsequently evaluated by the GeneMapper software (Applied Biosystems), and individually verified. Multilocus match analyses were evaluated by GenAlEx v. 6.502 (Peakall and Smouse 2012). The allele frequency analysis, including the number of total alleles scored $(\mathrm{Na})$, observed heterozygosity (Ho), expected heterozygosity (He), polymorphic information index (PIC) and the null allele frequency ( $\mathrm{F}$ null), were estimated by the program Cervus 3.0.7 (Kalinowski et al. 2007). The most abundant genotype occurring among the individuals of the grey 
poplar population was defined as the representative plant material for the following cryopreservation experiments.

Explant establishment and culture: Grey poplar (Populus $\times$ canescens Aiton Sm.) twigs bearing dormant buds (clone 18) were collected at the beginning of March from one tree more than 40 years old at Dyjákovice Village (N 48,78442 ${ }^{\circ}$ E 16,29252 ${ }^{\circ}$ in South Moravia, Czech Republic. After transfer into the laboratory, sterilization procedures of the dormant buds were followed in several steps: incubation for $20 \mathrm{~min}$ in Tween ${ }^{\circledR} 20$ ( 2 droplets per $10 \mathrm{~cm}^{3}$ ), $20 \mathrm{~min}$ in disinfecting solution KORSOLEX®plus $\left(25 \mathrm{~cm}^{3}\right.$ per $500 \mathrm{~cm}^{3}$ of distilled water), rinsing for $20 \mathrm{~min}$ in running tap water, $20 \mathrm{~min}$ incubation in $\mathrm{HgCl}_{2}\left(1 \mathrm{mg} \mathrm{dm}^{-3}\right)$, and subsequent removal to a laminar flow hood where they were submerged in sterile water three-times for $15 \mathrm{~min}$. To induce organogenesis, isolated shoot tips from dormant buds were placed on a modified MS medium enriched with $10 \mathrm{mg} \mathrm{dm}^{-3}$ glutamine, $2 \mathrm{mg} \mathrm{dm}^{-3}$ glycine, $0.2 \mathrm{mg} \mathrm{dm}^{-3}$ 6-benzylaminopurine (BAP), and $0.1 \mathrm{mg} \mathrm{dm}^{-3}$ indole-3butyric acid (IBA), containing $30 \mathrm{~g} \mathrm{dm}^{-3}$ sucrose and $6 \mathrm{~g}$ $\mathrm{dm}^{-3}$ agar, with the $\mathrm{pH}$ adjusted to 5.8 with $1 \mathrm{M} \mathrm{KOH}$. The segments were cultivated in controlled conditions at $24{ }^{\circ} \mathrm{C}$, a 16-h photoperiod, and an irradiance of $30 \mu \mathrm{mol} \mathrm{m}{ }^{-2} \mathrm{~s}^{-1}$. After approximately four weeks, the proliferation of the shoots was determined. Subculturing and multiplication of the explants was performed every third week on the same medium to ensure sufficient amounts of vital plant material.

Explant acclimation and vitrification procedure: In vitro cultures of grey poplar were divided into three groups (treatments $\mathrm{A}, \mathrm{B}, \mathrm{C}$ ) differing in preculture conditions, including different culture temperatures and osmotic treatments. Treatment A represented in vitro grown shoots, which were maintained in control conditions $\left(24^{\circ} \mathrm{C}, 16-\mathrm{h}\right.$ photoperiod, and an irradiance of $\left.30 \mu \mathrm{mol} \mathrm{m} \mathrm{m}^{-2} \mathrm{~s}^{-1}\right)$. The shoots of treatments $\mathrm{B}$ and $\mathrm{C}$ were cold hardened at $6{ }^{\circ} \mathrm{C}$ for four weeks under the same other conditions. The treatment $\mathrm{C}$ involved addition of $0.7 \mathrm{M}$ sucrose $\left(12.5 \mathrm{~cm}^{3}\right.$ was added as a solution on the top of $25 \mathrm{~cm}^{3}$ of agar medium into each glass jar by pipetting) for the third and fourth weeks of cold hardening, thus the final sucrose concentration, including sucrose in both, medium and solution, reached $0.3 \mathrm{M}$ in each culture vessel.

After four weeks of precultivation, isolated apical shoot tips (approximately 200 pieces of $2-3 \mathrm{~mm}$ length per treatment) were transferred into the Petri dishes (10 plant segments in one Petri dish) containing modified agar MS medium enriched with $0.3 \mathrm{M}$ sucrose and placed into a cultivation room overnight $\left(24{ }^{\circ} \mathrm{C}\right)$. A modified vitrification protocol described by Nishizawa et al. (1993) was applied with some modifications. Isolated shoot tips were transferred into $10 \mathrm{~cm}^{3}$ of loading solutions; LS [2 $\mathrm{M}$ glycerol and $0.4 \mathrm{M}$ sucrose, $\mathrm{pH} \mathrm{5.8]} \mathrm{for} 30 \mathrm{~min}$ at room temperature. The LS was removed and replaced with $10 \mathrm{~cm}^{3}$ of a half-concentrated plant vitrification solution 3 (PVS3; 2.7 M glycerol and 0.073 M sucrose) for $30 \mathrm{~min}$. Subsequently, the PVS3 solution was removed and replaced with $10 \mathrm{~cm}^{3}$ of modified PVS3 vitrification solution (80\%
PVS3 containing 4.34 M glycerol and 1.17 M sucrose). The samples were dehydrated by either 120,150 , or $240 \mathrm{~min}$, but they were not treated with liquid nitrogen. Before their recovery on growth medium, the shoot tips were treated with unloading solution containing $0.75 \mathrm{M}$ sucrose for $30 \mathrm{~min}$ to avoid their osmotic damage. Finally, ten shoot apices from each treatment were transferred to Petri dishes containing a modified MS medium enriched with phytohormones and other substances as described above for the induction and multiplication of the explants and placed into the growth room under the same conditions as described above but covered by a sheet of paper to prevent photoinhibition. Two weeks later, the survival of the shoot apices was evaluated. Segments were transferred into the same fresh medium where they remained until eight weeks for the final evaluation of the shoot tips regrowth percentage.

Ultra-rapid cooling by using liquid nitrogen: Isolated apical segments, pretreated accordingly as mentioned for treatment C and dehydrated in PVS3 for 180 or $240 \mathrm{~min}$, were directly transferred onto aluminium rectangles $(20 \times 6 \times 0.05 \mathrm{~mm})$ and cryopreserved by ultra-rapid cooling with liquid nitrogen $\mathrm{LN}\left(-196{ }^{\circ} \mathrm{C}\right)$. The highly viscous PVS solution tightly stuck the shoot tips to the aluminium rectangle without risk of their loss in the LN. They were in LN for a minimum of $1 \mathrm{~h}$. The individual rectangles with 10 shoot tips were quickly plunged into the $2 \mathrm{~cm}^{3}$ of polypropylene cryovials (Nunc, Fisher Scientific, location?) filled with LN for $60 \mathrm{~min}$. Samples were quickly thawed by transferring the aluminium foils from $\mathrm{LN}$ into a heated $\left(40^{\circ} \mathrm{C}\right)$ unloading solution of the same composition as described above. Ten shoot tips were subsequently transferred onto Petri dishes $(5 \mathrm{~cm}$ diameter) containing a modified MS medium enriched with phytohormones and other substances as described above, moved into the growth chamber, and covered with a sheet of paper to prevent photoinhibion. The shoot tip survival and regrowth were evaluated after two and eight weeks, respectively.

Measurement using DSC: Thermal analysis by the differential scanning calorimetry was performed during dehydration with cryoprotective solutions under different preculture conditions. The proportion of freezable water (percent of the fresh mass) was determined using a differential scanning calorimeter $Q 2000$ with a refrigerated cooling system (TA Instruments, New Castle, DE, USA) in the temperature range from -90 to $+20{ }^{\circ} \mathrm{C}$ at cooling and heating rates of $10^{\circ} \mathrm{C}$ per min with the use of hermetically sealed aluminium pans.

Data collection and statistical analysis: Three independent biological repetitions were conducted for all treatments with at least 10 samples per replicate. The data collected were evaluated using one-way analysis of variance. Statistically significant differences among the individual treatments are recorded based on all pairwise multiple comparison procedures according to the HolmSidak method at $\alpha=0.05$ (SigmaPlot 14.0, Systat Software, 
Hounslow, UK).

\section{Results}

Patterns of genetic diversity variation in thirty phenotypically valuable grey poplars growing at the floodplain forest in the South Moravia region of the Czech Republic were evaluated to select the most frequently occurring genotype among the individuals for further cryopreservation procedures. The nine SSR markers used in this study detected a total of 37 alleles ranging from 2 to 7 alleles, with an average number of total alleles scored representing 4.11 per locus. The most polymorphic loci exhibit ORPM30 and WPMS15 with polymorphic information index 0.527 and 0.524 , respectively, in contrast to the ORPM16 and ORPM312 loci (Table 1). According to the genetic characteristics evaluated, a very low genetic variability was detected in the collection of samples in this study (Table 1). In addition, the multilocus matches of the microsatellite analysis revealed only 5 different genotypes in the group of 30 individuals of selected grey poplars. Individuals of the female sex, which were determined later during flowering time, represented 28 samples with the most prevailing genotype detected for 26 of them (online resources 1). In summary, our data point to a low allelic diversity in the population studied and reveal a clonal identity for 26 grey poplars, which we consequently used as a representative clone for our longterm storage experimental study.

Apical shoot tips isolated from non-acclimated explants of grey poplar (treatment A) tolerated their exposure to $0.3 \mathrm{M}$ sucrose in modified MS medium for overnight and subsequent LS or PVS3 treatments for 30 min without significant decrease in their regrowth and regeneration. However, they showed a decline in their regrowth and regeneration after PVS3 treatment for 120, 180, and 240 min when compared to treatments $\mathrm{B}$ and $\mathrm{C}$. The minimal average two-week recovery of shoot tips from nonacclimated explants dropped to $23.3 \pm 5.8 \%$ (Fig. 1A). In cold-acclimated explants (treatment $\mathrm{B}$ ), tolerance to dehydration of isolated shoot tips improved significantly, when compared to the non-acclimated explants, and the minimal average explant regrowth, after two-week recovery, increased to $65 \pm 21.2 \%$ (Fig. $1 A$ ). Simultaneous effect of cold acclimation and osmotic treatment with sucrose solution (treatment $\mathrm{C}$ ) had the highest positive effect on increase of dehydration tolerance which increased to $83.3 \pm 15.3 \%$ (Fig. $1 A$ ). The increase in dehydration tolerance of isolated grey poplar shoot tips after explant acclimation by simultaneous cold and osmotic treatment was confirmed after eight-week recovery (Fig. $1 B$ ). These explants exposed to PVS3 for 120 and $150 \mathrm{~min}$ achieved the highest regrowth percentage (93.3 and $90.0 \%$, respectively) in comparison to non-acclimated (60 \pm $10 \%$ and $46.7 \pm 5.8 \%$, respectively) and cold-acclimated explants $(56.7 \pm 20.8 \%$ and $56.7 \pm 15.3 \%)$ (Fig. $1 B)$. However, the shoot tip regrowth substantially decreased after 240 min of PVS3 exposures in treatment $\mathrm{C}$ up to $83.3 \pm 15.3 \%$. Our results confirmed the positive effect of cold and osmotic acclimation on dehydration tolerance of isolated grey poplar shoot tips.

The freezable water content in isolated shoot tips was influenced by pre-culture conditions (treatments A, B, and C). Non-acclimated control samples (treatment A) had a higher water content $(85.3 \pm 9.1 \%)$ than the acclimated plants (treatments B and C) containing $73.2 \pm 4.5 \%$ and $64.5 \pm 2.3 \%$ of freezable water, respectively. Subsequent 30 min treatments with LS and PVS3 caused a decline of the freezable water content of isolated shoot tips in all treatments and the sharpest reduction was observed after the 120 min PVS3 treatment (Fig. 2). Following incubation in PVS3 slowly dehydrated the plant samples across the 120 - $240 \mathrm{~min}$ interval (Fig. 2), but these changes in freezable water content were not statistically significant. The content of freezable water after the PVS3 solution exposure decreased from $5.6 \pm 0.4$ to $1.7 \pm 1.6 \%$ in treatment $\mathrm{A}$, whereas from $4.1 \pm 1.3$ to $0.8 \pm 0.3 \%$ and from $4.3 \pm 1.3$ to $0.9 \pm 0.1 \%$ in treatments $\mathrm{B}$ and $\mathrm{C}$, respectively. Our results demonstrate that pre-cultivation conditions and the subsequent cryoprotectant treatment had significant effects on the content of freezable water in plant tissues. It was proved that PVS3 was very efficient in dehydration of isolated shoot tips of grey poplar.

Two important findings, 1) simultaneous cold and osmotic acclimation increased dehydration tolerance (treatment C) and 2) successful PVS3 dehydration reduced freezable water content, were employed to test their effect on grey poplar cryotolerance. Due to a lack of significant differences among the regeneration rate of the explants after dehydration for $120 \mathrm{~min}(93.3 \pm 5.8 \%)$ and $240 \mathrm{~min}$ $(83.3 \pm 8.8 \%)$ in PVS3 (Fig. 3), a shorter interval between $180 \mathrm{~min}$ and $240 \mathrm{~min}$ (in the end of PVS3 dehydration period) was selected to reach the optimal dehydration for the maximal post-thaw recovery. Prolonged exposure of PVS3 treatment allowed to reduce the freezable water content (approximately $1 \%$ ), which has not resulted in explant damage by excessive dehydration yet (Fig. 3). Cryopreserved apical shoot tips incubated for $180 \mathrm{~min}$ and $240 \mathrm{~min}$ in the cryoprotective solution exhibited only a slight difference on the regrowth of the shoot tips after two-week recovery (Fig. 4). After eight-week recovery, post-thaw regeneration reached $83.3 \pm 15.3 \%$ and $90 \pm 0 \%$ in explants incubated in PVS3 for 180 and 240 min, respectively (Fig. 3). The statistically significant difference in explants regeneration after 180 and $240 \mathrm{~min}$ of cryoprotective solution treatment was not proved. In summary, even though no significant differences have been observed among the shoot tips treated by PVS3 cryoprotectant for 180 or $240 \mathrm{~min}$, the regrowth percentage of grey poplar after thawing from the liquid nitrogen was higher than $80 \%$ after 8 weeks of evaluation.

\section{Discussion}

The aim of this work was a preservation of valuable genotypic and phenotypic traits of grey poplar (Populus $\times$ canescens Aiton Sm.) originating from a unique population located in a floodplain forest in the South Moravia region 
Table 1. Genetic diversity parameters in selected 30 grey poplar (Populus $\times$ canescens Aiton Sm.) individuals. Na - number of observed alleles, Ho - observed heterozygosity, He - expected heterozygosity, PIC - polymorphic information content, HW - Hardy-Weinberg expectations, F null - null allele frequency, ND - not determined, **, *** deviations from HW significant at 0.01 and 0.001 probability level, respectively.

\begin{tabular}{lllllll}
\hline Locus name & $\mathrm{Na}$ & $\mathrm{Ho}$ & $\mathrm{He}$ & $\mathrm{PIC}$ & $\mathrm{HW}$ & F null \\
\hline ORPM220 & 3 & 1 & 0.54 & 0.421 & $* * *$ & -0.3154 \\
ORPM16 & 3 & 0.1 & 0.098 & 0.094 & $\mathrm{ND}$ & -0.0161 \\
WPMS5 & 5 & 0.067 & 0.247 & 0.235 & $\mathrm{ND}$ & 0.6264 \\
WPMS15 & 5 & 1 & 0.615 & 0.524 & $* * *$ & -0.2656 \\
ORPM20 & 5 & 0.967 & 0.572 & 0.466 & $* * *$ & -0.2894 \\
WPMS16 & 5 & 1 & 0.601 & 0.506 & $* * *$ & -0.2747 \\
ORPM30 & 7 & 1 & 0.616 & 0.527 & $* * *$ & -0.2652 \\
ORPM312 & 2 & 0 & 0.127 & 0.117 & ND & 0.8138 \\
ORPM60 & 2 & 0.867 & 0.499 & 0.371 & $* *$ & -0.2765 \\
\hline
\end{tabular}

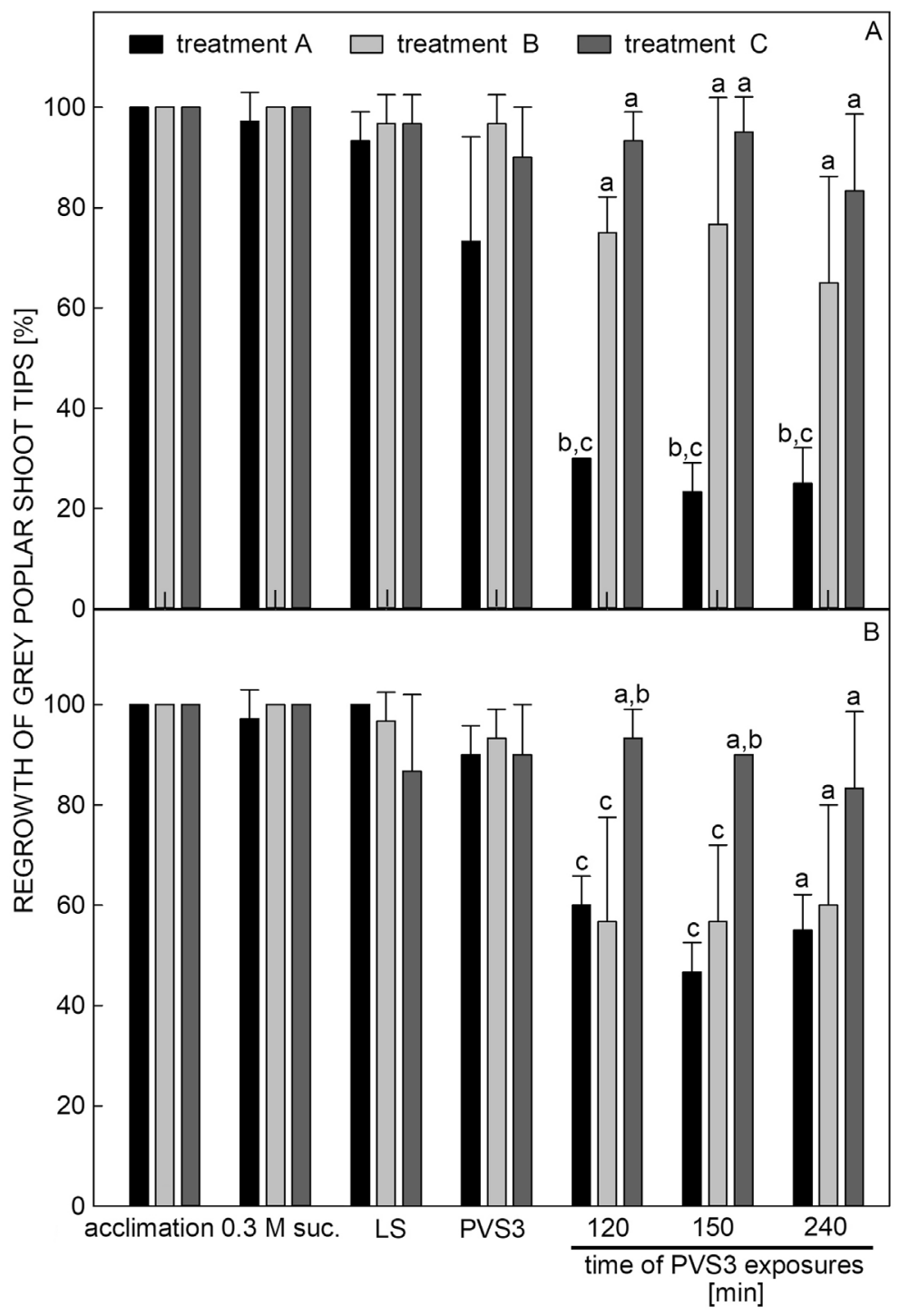

Fig. 1. The effect of pretreatment conditions on the regrowth of the grey poplar (Populus $\times$ canescens Aiton Sm.) shoot tips evaluated after two $(A)$ and eight $(B)$ weeks of cultivation on a modified Murashige and Skoog medium. Pretreatment conditions: treatment $\mathrm{A}$ - no acclimation, treatment $\mathrm{B}$ - cold hardening $\left(6^{\circ} \mathrm{C}\right)$, treatment $\mathrm{C}$ - cold hardening $\left(6^{\circ} \mathrm{C}\right)$ with incubation in sucrose $(0.3 \mathrm{M})$. LS - loading solution, PVS3 - modified plant vitrification solution. Means \pm SEs, $n=3$, different letters indicate statistically significant differences at $P<0.05$. 
of the Czech Republic and endangered by attacks of fungal pathogens. The first task, the determination of the genetic diversity of grey poplar, was performed using nine polymorphic microsatellite loci (SSR markers), which discriminated the repeated genotypes among the 30 selected individuals (Table 1 Suppl.). According to the reduced area of sampling (the longest distance between samples was $2.5 \mathrm{~km}$ ) the number of individuals analysed (30) and the number and type of SSR markers used (9 SSR), we found a clonality prevalence for 26 of them, the high frequency (more than $86 \%$ ) of the most abundant genotype in the population showed that this population was more clonal than sexual. Low allelic diversity was observed for an additional 125 samples collected in the same area where a clonal identity for most of the samples was determined using 5 additional SSR markers (Pokorná et al. 2018). Similarly, Fussi et al. (2012) found identical genotypes of Populus alba in all 28 samples taken from different valleys of the island Malta, one of the grey poplar parents. In addition, it is generally known that the genus Populus is characterized by a high ability for clonal propagation primarily by sprouting, which leads to a broad extension of only one clone on the area as reported, e.g., Kemperman and Barnes (1976) and DeWoody et al. (2008), for the giant clone of Populus tremuloides occupying $4330 \mathrm{~m}^{2}$ and containing 47000 ramets. Interestingly, we identified a disproportion in the female and male sex occurrence during the collection of samples with the most abundant female sex characterized for 26 of them by the same allele sizes determined by the 9 SSR markers. Currently, the detection of diversity in monoclonal poplar stands is linked to the application of other approaches than using the SSR method, such as epigenetic diversity determining the DNA methylation status (Guarino et al. 2015) or looking for single nucleotide polymorphism markers (SNPs), which appear to exhibit a slightly higher average of differentiation then the other types of codominant markers (Ingvarsson et al. 2005, Keller et al. 2010, Olson et al. 2010).

The predominant and representative genotypes (Table 1) of the native grey poplar population was selected for their preservation due to its valuable features such as a narrow crown and a straight continuous trunk with natural pruning (Buriánek and Novotný 2016). The high frequency of this genotype in the population indicates its very high vitality and competitiveness in spreading in the environment. Thus, in addition to its valuable properties, this genotype has also a very high potential for its successful cultivation in forests. It has been shown, using five chestnut clones, that genotype specificity might substantially affect shoot recovery after thawing from the liquid nitrogen temperature from 38 - $54 \%$ (Vidal et al. 2005), which has also been reported for 6 lines of in vivo hybrid aspen buds, in which the regrowth rate ranged from $59-95 \%$ and $72-96 \%$ after 2 and 4 weeks of cultivation, respectively (Jokipii et al. 2004). Similarly, a variable regeneration rate of shoot tips was observed among four apple cultivars non-cryopreserved as well as after storage in liquid nitrogen (Halmagyi et al. 2010).

In our study, we used a vitrification procedure employing the modified PVS3 solution for the first time to test its effect on the post-thaw recovery of grey poplar shoot tips. The success of cryopreservation is influenced by the sensitivity of the genotype to a particular cryopreservation process, and usually involves sensitivity to strong dehydration of the tissues (Benson 2008). Because the cryotolerance is not a natural ability of any species, improvement of dehydration tolerance can be a way how to cope with the cryopreservation conditions. An assumption that a high dehydration tolerance allows a very massive water content decrease which limits ice development and growth during

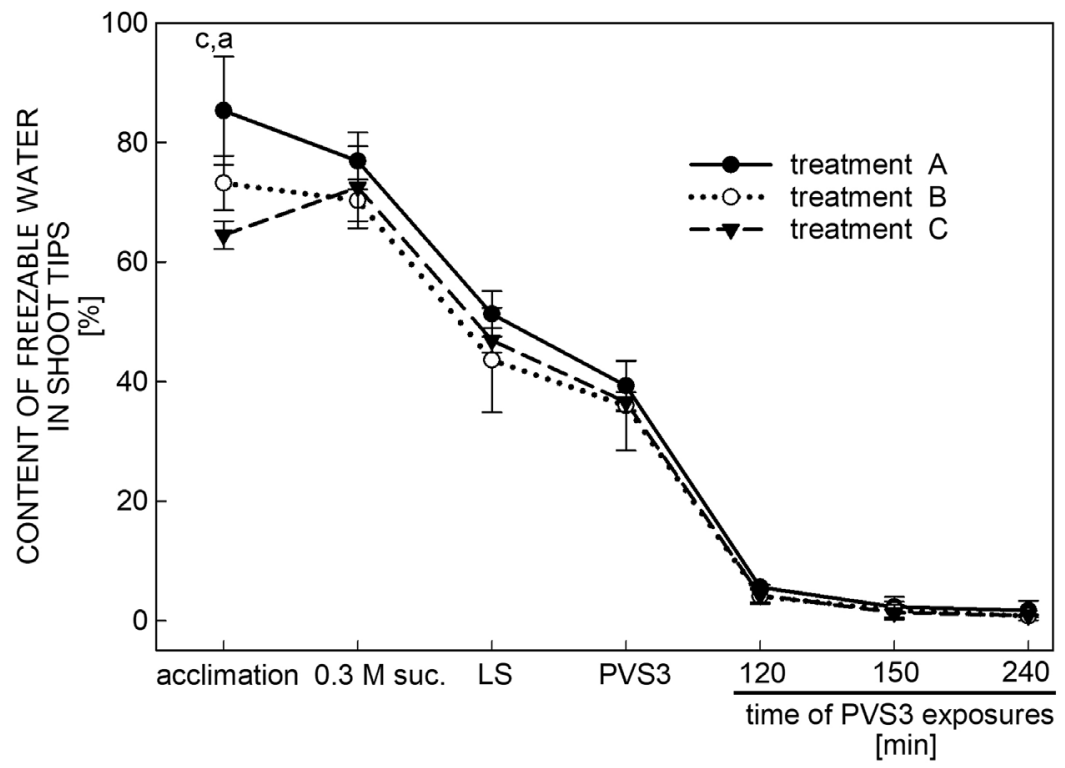

Fig. 2. The effect of pretreatment conditions on the content of freezable water content in grey poplar (Populus $\times$ canescens Aiton Sm.) shoot tips. Pretreatment conditions: treatment A - no acclimation, treatment B - cold hardening $\left(6^{\circ} \mathrm{C}\right)$, treatment $\mathrm{C}$ - cold hardening $\left(6{ }^{\circ} \mathrm{C}\right)$ with incubation in sucrose $(0.3 \mathrm{M})$. LS - loading solution, PVS3 - modified plant vitrification solution. Means $\pm \mathrm{SEs}, n=3$, different letters indicate statistically significant differences at $P<0.05$. 
explants cooling to an ultra-low temperature $\left(-196^{\circ} \mathrm{C}\right)$ can be defined. Thus, we formulated the hypothesis that grey poplar explant acclimation by cold or osmotic treatments and following decrease in freezable water content improve their cryotolerance.

Three different preculture conditions were tested: A-no acclimation, B - cold hardening, and C - simultaneous effect of cold hardening and osmotic treatment. Treatments employing a low temperature acclimation (Bilavcik et al. 2012) or a simultaneous low temperature and osmotic treatment (Faltus et al. 2011) have been used successfully for acclimation of explants before their cryopreservation. In our study, treatment $A$ had no significant effect on the explant regrowth, but it resulted in the different sensitivity

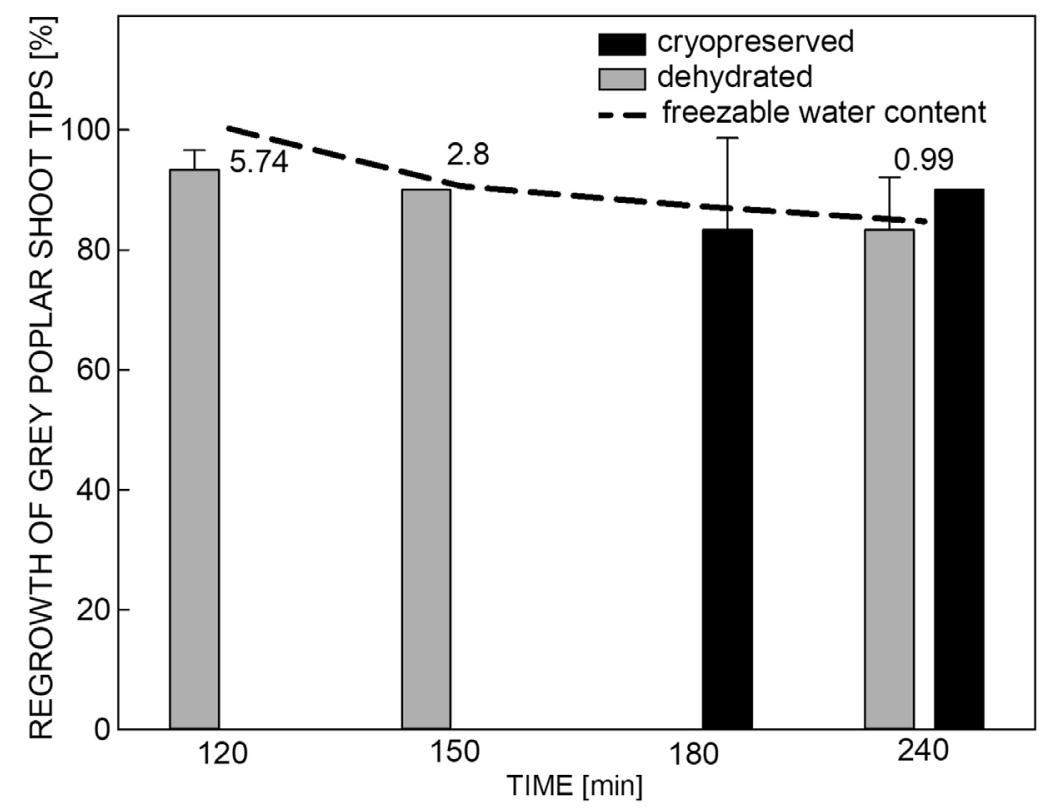

Fig. 3. The effect of plant vitrification solution 3 application on grey poplar (Populus $\times$ canescens Aiton Sm.) shoot tips after dehydration and then cryopreservation in liquid nitrogen. The shoot tips were pretreated by cold hardening with the application of $0.7 \mathrm{M}$ sucrose. The regrowth and content of freezable water was evaluated after eight weeks of segment cultivation on a modified Murashige and Skoog medium. Means $\pm \mathrm{SEs}, n=3$. No significant differences in the regrowth percentage was found.

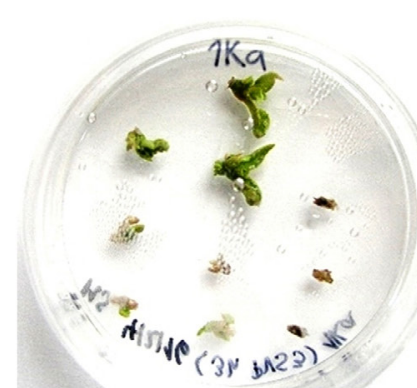

A

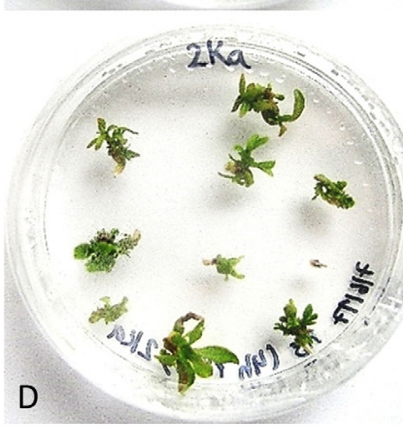

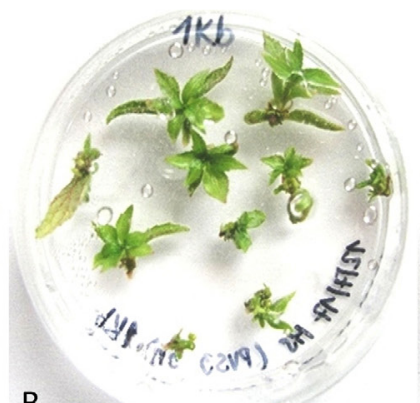

B

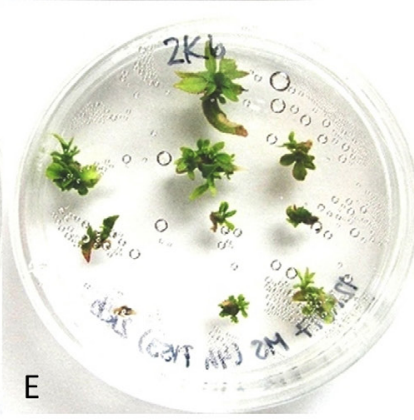

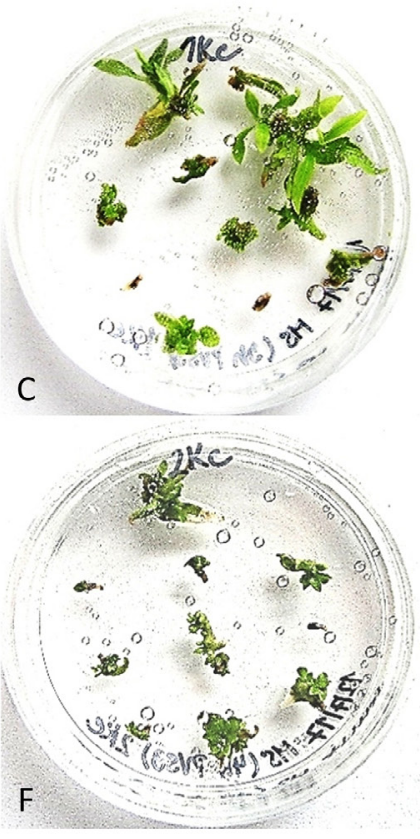

F

Fig. 4. The effect of plant vitrification solution 3 (PVS3) application on grey poplar (Populus $\times$ canescens Aiton Sm.) shoot tip regrowth after cryopreservation in liquid nitrogen evaluated after two weeks of cultivation on a modified Murashige and Skoog medium. The shoot tips were pretreated by cold hardening $\left(6^{\circ} \mathrm{C}\right)$ and $0.3 \mathrm{M}$ sucrose followed by incubation for $180 \min (A-C)$ and $240 \mathrm{~min}(D-F)$ in $80 \%$ PVS3. The diameter of Petri dish was $70 \mathrm{~mm}$. 
of explants to dehydration using the cryoprotective solution PVS3 (Fig. 1). However, the explant acclimation significantly decreased the freezable water content determined by DSC. Similarly, a frozen water content decrease was measured by DSC in encapsulated Theobroma cacao somatic embryos subjected to $0.08-1.25 \mathrm{M}$ sucrose (Fang et al. 2009). The decrease in freezable water content confirmed the ability of grey poplar explants to acclimate to a low temperature and osmotic stress. This reduction in the freezable water content can occur due to a decrease in the total water content and/or osmotic adjustment, i.e., the accumulation of osmotically active substances such as soluble sugars (Beck et al. 2007).

The next steps of the vitrification procedure including the treatment of isolated shoot tips with $0.3 \mathrm{M}$ sucrose overnight, $30 \mathrm{~min}$ treatment with LS and following $30 \mathrm{~min}$ treatment with PVS3 did not significantly decrease the regrowth of the explants, but the last treatment resulted in a significant decrease in freezable water content (Fig. 1). Gradual tissue dehydration as well as employment of $80 \%$ PVS3 instead of concentrated PVS3 solution helps avoiding the strong osmotic stress and explants injury during vitrification protocol (Faltus et al. 2015). Any significant differences in the freezable water content and melting temperature among the three experimental treatments tested were not detected in the individual steps of the vitrification procedure with the exception of the preculture treatments described above. That shows the decisive effect of particular cryoprotective solutions on thermal characteristics at steady-state conditions after 30 min of their treatments.

The final step of the vitrification procedure, a strong dehydration by the cryoprotective solution PVS3, significantly decreased the freezable water content in all the treatments tested. The decrease in the water content is a prerequisite for successful cryopreservation, but it can result in explant injury due to dehydration or the cryoprotectant influence (Valk and Walters 2006). Grey poplar explant dehydration resulted in a decrease in their regrowth, but the reduction depended on the preculture conditions tested. Maximal recovery of explant treated with PVS3 and evaluated after 2 weeks of shoot tip regrowth reached $30.0 \pm 0.0 \%, 76 \pm 25.2 \%$, and $95 \pm 7.1 \%$ in treatments $\mathrm{A}, \mathrm{B}$, and $\mathrm{C}$, respectively (Fig. 1A). The most sensitive to dehydration were the non-acclimated explants, which exhibited the statistical significant difference compared to treatments $\mathrm{B}$ and $\mathrm{C}$ after both two and eight weeks of regrowth (Fig. 1B). The explants from treatment $\mathrm{C}$ exhibited the highest regrowth percentage $(93.3 \pm 5.8 \%$ after $120 \mathrm{~min}$ of PVS3 exposure) after 8 weeks compared to treatments $\mathrm{A}$ and $\mathrm{B}$, which is higher than after the PVS2 application at $0{ }^{\circ} \mathrm{C}$ for $60 \mathrm{~min}$ resulting in a survival percentage of $90 \%$ of the white poplar axillary buds precultured on the MS medium containing $0.09 \mathrm{M}$ sucrose (Caccavale et al. 1998). However, not only temperature and the time of plant vitrification solution exposures are important factors for plant regeneration, as reported by Lambardi et al. (2000), who showed that sucrose concentration in the preculture medium could also significantly reflect the shoot tip survival of white poplar.
Thus, grey poplar is a very suitable woody plant species to follow the individual cryoconservation procedures in a short time due to a fast shoot proliferation and multiplication of the explants as well as the low requirements of the specific cultivation conditions such as a composition of nutrients or phytohormones in a medium (Žižková et al. 2017). Similarly, we observed quickly developing green plantlets on the modified MS medium two weeks after thawing (Figs 3 and 4). Treatment $\mathrm{C}$ was selected for the experiments with liquid nitrogen. The explant recovery after the LN treatment was $76.7 \pm 5.8 \%$ and $73.3 \pm 20.8 \%$ after 2 weeks for explants dehydrated for 180 and $240 \mathrm{~min}$, respectively, and after 8 weeks, it was $83.3 \pm 15.3 \%$ and $90 \pm 0.0 \%$, and the differences between the two exposure times of PVS3 treatment were not significant in both terms of explant evaluation. A rapid immersion in LN and rewarming samples maintained a high regeneration of grey poplar explants treated for $240 \mathrm{~min}$ in PVS3 up to $90 \%$, which is comparable with the regeneration of the noncryopreserved shoot tips from treatment $\mathrm{C}$ varying from $93.3 \pm 3.3$ to $83.3 \pm 8.8 \%$ (Fig. 3). This finding shows that the regeneration potential of the dehydrated explants was maximally utilized and no serious injury of the poplar explants caused by liquid nitrogen was observed. We can summarize that an appropriate way of explant acclimation and an efficient decrease in freezable water content can shift the biological limits of cryotolerance in the plant kingdom.

\section{Conclusions}

Cryogenic techniques and molecular genetics were combined to preserve a representative clone of grey poplar population (Populus $\times$ canescens Aiton Sm.) valuable for its phenotype traits and as a source for the replacement of withering and dying ash and alder stands attacked by fungal pathogens at several localities of the floodplain forest in the Czech Republic. The hypothesis that a specific explant preculture and a decrease in the freezable water content improve the cryotolerance of grey poplar shoot tips has been proved. Simultaneous cold and osmotic treatments increased grey poplar dehydration tolerance, which allowed a considerable freezable water content decrease without a serious injury of explants. For the first time, a vitrification procedure based on the PVS3 cryoprotective solution was successfully tested for the cryopreservation of grey poplar explants. The results achieved will allow saving the unique, the most abundant genotype of grey poplar in the South Moravia region, and they will help to recover and expand this genotype in the future.

\section{References}

Beck, E.H., Fettig, S., Knake, C., Hartig, K., Bhattarai, T.: Specific and unspecific responses of plants to cold and drought stress. - J. Biosci. 32: 501-510, 2007.

Benelli, C., De Carlo, A., Engelmann, F.: Recent advances in the cryopreservation of shoot-derived germplasm of 
economically important fruit trees of Actinidia, Diospyros, Malus, Olea, Prunus, Pyrus and Vitis. - Biotechnol. Adv. 31: 175-185, 2013.

Benson, E.E.: Cryopreservation theory. - In: Reed, B.M. (ed.): Plant Cryopreservation: A Practical Guide. Vol. 2. Pp. 15-31. Springer, Dordrecht 2008.

Benson, E.E.: An introduction to plant cryopreservation biotechnology. - In: Benson, E.E. (ed.): Plant Conservation Biotechnology. Pp. 3-9. CRC Press, London 1999.

Bilavcik, A., Zamecnik, J., Faltus, M.: Cryotolerance of apple tree bud is independent of endodormancy. - Front. Plant. Sci. 6: 1-13, 2015.

Buriánek, V., Novotný, P.: Metodická př́ručka k určování domácích druhů topolů. [Methodological Manual for Native Poplar Species Determination.] - VúLHM, Strnady 2016. [In Czech]

Caccavale, A., Lambardi, M., Fabbri, A.: Cryopreservation of woody plants by axillary bud vitrification: a first approach with poplar. - Acta hort. 457: 79-84, 1998.

Danso, K.E., Ford-Lloyd, B.V.: Cryopreservation of cassave micropropagules using simple slow freezing and vitrification techniques. - Biotechnology 10: 415-420, 2011.

De Woody, J., Rowe, C.A., Hipkins, V.D., Mock, K.E.: „Pando“ lives: molecular genetic evidence of a giant aspen clone in central Utah. Western North Amer. Natur. 68: 493-497, 2008.

Fahy, G.M., Macfarlane, D.R., Angell, C.A., Meryman, H.T.: Vitrification as an approach to cryopreservation. Cryobiology. 21: 407-426, 1984.

Faltus, M., Zamecnik, J., Svoboda, P., Patzak, J., Nesvadba, V.: Progress in the Czech hop germplasm cryoconservation. - Acta. hort. 908: 453-460, 2011.

Faltus, M., Bilavcik, A., Zamecnik, J.: Thermal analysis of grapevine shoot tips during dehydration and vitrification. Vitis 54: 243-245, 2015.

Fang, J.Y., Sacandé, M., Pritchard, H., Wetten, A.: Influence of freezable/non-freezable water and sucrose on the viability of Theobroma cacao somatic embryos following desiccation and freezing. - Plant Cell Rep. 28: 883-889, 2009.

Fussi, B., Bonello, J., Calleja, E., Heinze, B.: Combining the use of molecular techniques and archival documentary evidence to trace the origin of Populus alba in a Central Mediterranean archipelago. - Eur. J. Forest Res. 131: 347-354, 2012.

Gantait, S., Sinniah, U.R., Suranthran, P., Palanyandy, S.H., Subramaniam, S.: Improved cryopreservation of oil palm (Elaeis guineensis Jacq.) polyembryoids using droplet vitrification approach and assessment of genetic fidelity. Protoplasma 252: 89-101, 2015.

Gill, P., Moghadam, T.T., Ranjbar, B.: Differential scanning calorimetry techniques: applications in biology and nanoscience. - J. Biomol. Tech. 21: 167-193, 2010.

Guarino, F., Cicatelli, A., Brundu, G., Heinze, B., Castiglione, S.: Epigenetic diversity of clonal white poplar (Populus alba L.) populations: could methylation support the success of vegetative reproduction strategy? - PLOS ONE 10: 1-20, 2015.

Guo, M., Littlewood, J., Joyce, J., Murphy, R.: The environmental profile of bioethanol produced from current and potential future poplar feedstocks in the EU. - Green. Chem. 16: 46804695, 2014.

Guzmán, L.F., Machida-Hirano, R., Borrayo, E., Cortés-Cruz, M., Espíndola-Barquera, M.D., Heredia García, E.: Genetic structure and selection of a core collection for long term conservation of avocado in Mexico. - Front. Plant. Sci. 8: 243-253, 2017.

Halmagyi, A., Deliu, C., Isac, V.: Cryopreservation of Malus cultivars: comparison of two droplet protocols. - Scientia Hort. 124: 387-392, 2010.

Ingvarsson, P.K.: Nucleotide polymorphism and linkage disequilibrium within and among natural population of european aspen (Populus tremula L., Salicaceae). - Genetics 169: 945-953, 2005.

Jokipii, S., Ryynänen, L., Kallio, P.T., Aronen, T., Häggman, H.: A cryopreservation method maintaining the genetic fidelity of a model forest tree, Populus tremula L. $\times$ Populus tremuloides Michx. - Plant. Sci. 166: 799-806, 2004.

Kaczmarczyk, A., Funnekotter, B., Menon, A., Phang, P.Y., AlHanbali, A., Brunn, E., Mancera, R.L.: Current issues in plant cryopreservation. - In: Katkov, I. (ed.): Current Frontiers in Cryobiology. Vol. 14. Pp. 417-438. http://www.intechopen. com/books 2012.

Kalinowski, S.T., Taper, M.L., Marshall, M.C.: Revising how the computer program CERVUS accomodates genotyping error increases success in paternity assignment. - Mol. Ecol. 16: 1099-1106, 2007.

Kaviani, B.: Conservation of plant genetic resources by cryopreservation. - Aust. J. Crop. Sci. 6: 778-800, 2011.

Kemperman, J.A., Barnes, B.V.: Clone size in American aspens. - Can. J. Bot. 54: 2603-2607, 1976.

Keller, S.R., Olson, M.S., Silim, S., Schroeder, W., Tiffin, P.: Genomic diversity, population structure, and migration following rapid range expansion in the balsam poplar, Populus balsamifera. - Mol. Ecol. 19: 1212-1226, 2010.

Kim, H.H., Lee, Y.G., Shin, D.J., Ko, H.C., Gwag, J.G., Cho, E.G., Engelmann, F.: Development of alternative plant vitrification solutions in droplet-vitrification procedures. CryoLetters 5: 320-324, 2009.

Lambardi, M., Fabbri, A., Caccavale, A.: Cryopreservation of white poplar (Populus alba L.) by vitrification of in vitrogrown shoot tips. - Plant Cell Rep. 19: 213-218, 2000.

Liesebach, H., Schneck, V., Ewald, E.: Clonal fingerprinting in the genus Populus L. by nuclear microsatellite loci regarding differences between sections, species and hybrids. - Genet. Genomes 6: 259-269, 2010.

Marshall, T.C., Slate, J., Kruuk, L.E., Pemberton, J.M.: Statistical confidence for likehood-based paternity inference in natural populations. - Mol. Ecol. 7: 639-655, 1998.

Murashige, T., Skoog, F.: A revised medium for rapid growth and bioassays with tobacco tissue cultures - Physiol. Plant. 15: 473-497, 1962.

Nadarajan, J., Manson, M., Krishnapillay, B., Staines, H.J., Benson, E.E., Harding, K.: Applications of differential scanning calorimetry in developing cryopreservation strategies for Parkia speciosa, a tropical tree producing recalcitrant seeds. - CryoLetters 29: 95-110, 2008.

Nishizawa, S., Sakai, A., Amano, Y., Matsuzawa, T.: Cryopreservation of asparagus (Asparagus officinalis L.) embryogenic suspension cells and subsequent plant regeneration by vitrification. - Plant. Sci. 91: 67-73, 1993.

Nuc, K., Marszalek, M., Pukacki, P.M.: Cryopreservation changes the DNA methylation of embryonic axes of Quercus robur and Fagus sylvatica seeds during in vitro culture. Trees 5: 1831-1841, 2016.

Olson, M.S., Robertson, A.L., Takebayashi, N., Silim, S., Schroeder, W.R., Tiffin, P.: Nucleotide diversity and linkage disequilibrium in balsam poplar (Populus balsamifera). New Phytol. 186: 526-536, 2010.

Peakall, R., Smouse, P.E.: GenAlEx 6.5: genetic analysis in Excel. Population genetic software for teaching and research. - Bioinformatics 28: 2537-2539, 2012.

Pokorná, E., Buriánek, V., Máchová, P., Dostál, J., Komárková, M.: Nové poznatky o reprodukci topolu šedého $\mathrm{v}$ in vitro 
podmínkách. [New insight into the reproduction of grey poplar in in vitro conditions.] - Zprávy lesnického výzkumu 62: 213-223, 2017.

Pokorná, E., Č́̌žková, L., Máchová, P., Cvrčková, H., Buriánek, V., Komárková, M., Dostál, J., Čáp, J., Fulín, M.: Charakterizace genetické variabilitylokální populace topolu šedého (Populus $\times$ canescens Aiton Sm.) v Dyjákovicích s využitím SSR markerů a fenotypového hodnocení. [Characterization of genetic diversity of local population grey poplar (Populus $\times$ canescens Aiton Sm.) at Dyjákovice using SSR markers and phenotypic evaluation. Zprávy lesnického výzkumu 63: 281289, 2018.

Politov, D.V., Belokon, M.M., Belokon, S.Y., Polyakova, V.M., Shatokhina, V.A., Mudrik, A.E., Azarova, B.A., Filippov, V.M., Shestibratov, A.K.: Application of microsatellite loci for molecular identification of elite genotypes, analysis of clonality, and genetic diversity in aspen Populus tremula L. (Salicaceae). - Int. J. Plant. Genom. 2015: 261518-251529, 2015.

Pritchard, H.W., Moat, J.F., Ferraz, B.S., Marks, T.R., Camargo, J.L.C., Nadarajan, J., Ferraz, D.K.: Innovative approaches to the preservation of forest trees. - Forest. Ecol. Manage. 333: 88-98, 2014.

Reed, B.M.: Implementing cryogenic storage of clonally propagated plants. - CryoLetters 22: 97-104, 2001.

Ryynänen, L.: Effect of early spring birch bud type on post-thaw regrowth after prolonged cryostorage. - Can. J. Forest Res. 29: 47-52, 1999.

Ryynänen, L., Aronen, T.: Vitrification, a complementary cryopreservation method for Betula pendula Roth. Cryobiology 51: 208-219, 2005.

Sakai, A., Kobayashi, S., Oiyama, I.: Cryopreservation of nucellar cells of navel orange (Citrus sinensis Osb. var. brasiliensis Tanaka) by vitrification. - Plant Cell Rep. 9: 30-33, 1990.

Sales, E., Nebauer, S.G., Arrilaga, I., Segura, J.: Cryopreservation of Digitalis obscura genotypes by encapsulation-dehydration. - Plant. med. 67: 833-838, 2001.

Storme, V., Broeck, A.V., Ivens, B., Halfmaerten, D., Van Slycken, J., Castiglione, S., Grassi, F., Fossati, T., Cottrell, J.E., Tabbener, H.E., Lefèvre, F., Saintagne, C., Fluch, S., Krystufek, V., Burg, K., Bordács, S., Borovics, A., Gebhardt, K., Vornam, B., Pohl, A., Alba, N., Agúndez, D., Maestro, C., Notivol, E., Bovenschen, J., van Dam, B.C., van der Schoot, J., Vosman, B., Boerjan, W., Smulders, M.J.M.: Exsitu conservation of black poplar in Europe: genetic diversity in nine gene bank collections and their value for nature development. - Theor. appl. Genet. 108: 969-981, 2004.

Smulders, M.J.M., Van der Schoot, J., Arens, P., Vosman, B.: Trinucleotide repeat microsatellite markers for black poplar
(Populus nigra L.). - Mol. Ecol. Notes. 1: 188-190, 2001.

Tsvetkov, I., Benelli, C., Capuana, M., De Carlo, A., Lambardi, L.: Application of vitrification-derived cryotechniques for long-term storage of poplar and aspen (Populus spp.) germplasm. - Agr. Food Sci. 18: 160-166, 2009.

Tuskan, G.A., Gunter, L.E., Yang, Z.K., Yin, T.M., Seweli, M.M., Difazio, S.P.: Characterization of microsatellites revealed by genomic sequencing of Populus trichocarpa. - Can. J. Forest Res. 34: 85-93, 2004.

Uchendu, E.E., Leonard, S.W., Traber, M.G., Reed, B.M.: Vitamins $\mathrm{C}$ and $\mathrm{E}$ improve regrowth and reduce lipid peroxidation of blackberry shoot tips following cryopreservation. - Plant Cell Rep. 29: 25-35, 2010.

Urrestarazu, J., Denancé, C., Ravon, E., Guyader, A., Guisnel, R., Feugey, L., Poncet, C., Lateur, M., Houben, P., Ordidge, M., Fernandez-Fernandez, F., Evans, K.M., Paprstein, F., Sedlak, J., Nybom, H., Garkava-Gustavsson, L., Miranda, C., Gassmann, J., Kellerhals, M., Suprun, I., Pikunova, A.V., Krasova, N.G., Torutaeva, E., Dondini, L., Tartarini, S., Laurens, F., Durel, C.E.: Analysis of the genetic diversity and structure across a wide range of germplasm reveals prominent gene flow in apple at the European level. - BMC Plant Biol. 16: 130-150, 2016.

Úradníček, L., Maděra, P., Tichá, S., Koblížek, J. (ed.): Dřeviny České Republiky. [Trees of the Czech Republic.] Lesnická práce, Kostelec nad Černými lesy 2009. [In Czech]

Valk, G.M., Walters, C.: Plant vitrification solution 2 lowers water content and alters freezing behavior in shoot tips during cryoprotection. - Cryobiology 52: 48-61, 2006.

Van Loo, M., Joseph, A.F., Heinze, B., Fay, F.M., Lexer, C.: Clonality and spatial genetic structure in Populus $\times$ canescens and its sympatric backcross parent $P$. alba in a Central European hybrid zone. - New. Phytol. 177: 506-516, 2008.

Van der Schoot, J., Pospiskova, M., Vosman, B., Smulders, M.J.M.: Development and characterization of microsatellite markers in blackpoplar (Populus nigra L.). - Theor. appl. Genet. 101: 317-322, 2000.

Vidal, N., Sánchez, C., Jorquera, L., Ballester, A., Vieitez, A.M.: Cryopreservation of chestnut by vitrification of in vitro-grown shoot tips. - In Vitro cell. develop. Biol. 41: 63-68, 2005.

Wilkinson, T., Wetten, A., Prychid, C., Fay, M.F.: Suitability of cryopreservation for the long-term storage of rare and endangered plant species: a case history for Cosmos astrosanguineus. - Ann. Bot. 91: 65-74, 2003.

Žižková, E., Komárková, M., Máchová, P., Cvrčková, H.: Metoda rychlé regenerace topolu šedého (Populus $x$ canescence Aiton Sm.) s využitím in vitro organogeneze. [Methodology of rapid regeneration of Populus $x$ canescence Aiton Sm. using in vitro organogenesis.] - VÚLHM, Strnady 2017. [In Czech] 